\title{
Clay mineralogy of Miocene mudstones from the Lower Austrian Molasse Basin
}

\author{
Maria MESZAR ${ }^{*}$, Susanne GIER ${ }^{1}$, Markus PALZER-KHOMENKO${ }^{1}$, Wolfgang KNIERZINGER ${ }^{1}$ \& Michael WAGREICH ${ }^{1}$ \\ 1) Department of Geology, University of Vienna, Althanstraße 14, 1090 Wien, Austria \\ *) Corresponding author: maria.meszar@univie.ac.at
}

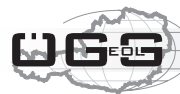

KEYWORDS Miocene, Ottnangian, clay mineralogy, Molasse Basin, Lower Austria

\begin{abstract}
Recent studies established the lithological and chemical sediment evolution in the Lower Austrian Molasse Basin (LAMB), a part of the North Alpine foreland basin, during the Early Miocene. In this study, we aim to integrate the clay mineralogy of seven wells across the LAMB with a newly proposed lithostratigraphy, and to infer implications for provenance, palaeogeography and palaeoclimate. The results of our qualitative and quantitative evaluation of the clay-sized fraction with $\mathrm{x}$-ray diffractometry largely support the stratigraphic model. The early stage of foreland basin formation (Egerian/Eggenburgian?) is represented by kaolinite contents up to $93 \%$ in the clay sized fraction. This indicates an orogen-external source, i.e. the Bohemian Massif, and erosion of intensively chemical weathered products during this early Molasse basin stage. The overlying marine Robulus Schlier (lower/middle Ottnangian) is characterized by a distinctly reduced kaolinite content and overall increased illite content compared to the other formations. Illite was predominantly provided from denudation of the rising Eastern Alps, i.e. characterizing the orogen-internal provenance. The pelites of the overlying carbonate poor Traisen Formation (upper Ottnangian) show again a higher kaolinite and smectite content. In the largely coeval basinal Wildendürnbach Formation, smectite reaches up to $70 \%$ in the clay sized fraction. Peak smectite values may be linked to volcanic ash input from the nearby Carpathian volcanic arc. Generally rising smectite versus illite ratios during the Ottnangian-Karpatian could point to a warming and intensified chemical weathering of the rising Alpine orogen.
\end{abstract}

\section{Introduction}

Mudstones and shales comprise a significant part of the basin fill and stratigraphy of the northern Alpine foredeep basin (e.g. Sant et al., 2017), a classical area of geological research on the Paratethys since the 18th century (de Saussure, 1779). Although a vast literature exists about the Molasse basin and its stratigraphy and sedimentology (for overviews see, e.g. Steininger and Wessely, 2000; Piller et al, 2007; Harzhauser and Mandic, 2008; Krijgsman and Piller, 2012; Kováč et al., 2017; Sant et al., 2017; Pippèrr and Reichenbacher, 2017; Pippèrr et al., 2018), the eastern part of the Lower Austrian Molasse Basin (LAMB) has been underexplored due to lack of surface outcrops (Wessely, 2006). This part of the Alpine foreland basin has only recently been put into the focus of more specific research due to exploration for hydrocarbons and other economic resources such as construction sand and groundwater (Palzer-Khomenko et al., 2018a, b). Especially the younger, Miocene part of the basin fill provides thick sandy intervals capped by clay-rich strata (Palzer-Khomenko et al., 2018a). The clay mineralogy and provenance of these fine-grained sediments in the basin subcrop have so far been largely unknown (Wimmer-Frey et al., 2013). Recent publications have mainly investigated the sands and sandstones regarding their lithostratigraphy, sedimentology and chemostratigraphy and log correlation (Palzer-Khomenko et al., 2018a, b), and examined the provenance of the sediments using heavy mineral analysis and mineral chemistry (Knierzinger et al., 2018, 2019).

The goal of this study is to identify possible differences and variations in the clay mineral assemblages within the mudstones of the LAMB. It is based on the sampling of well cuttings from a transect of seven wells in the area (Meszar, 2018), oriented from northeast to southwest (Fig. 1). Based on these results, the clay mineralogy of different lithological units is characterized, and stratigraphic implications and interpretations for provenance, foreland basin evolution and palaeoclimate are discussed.

\section{Geological and stratigraphical setting}

The study area is situated in the LAMB, the easternmost part of the Northern Alpine Foreland Basin (NAFB) in Austria. The NAFB extends into Bavaria and Switzerland in the west and into the Carpathian foredeep in the east, and formed part of the Western to Central Paratethys Sea. In Austria, the northern and northwestern border of this asymmetric foredeep basin is formed by the stable 


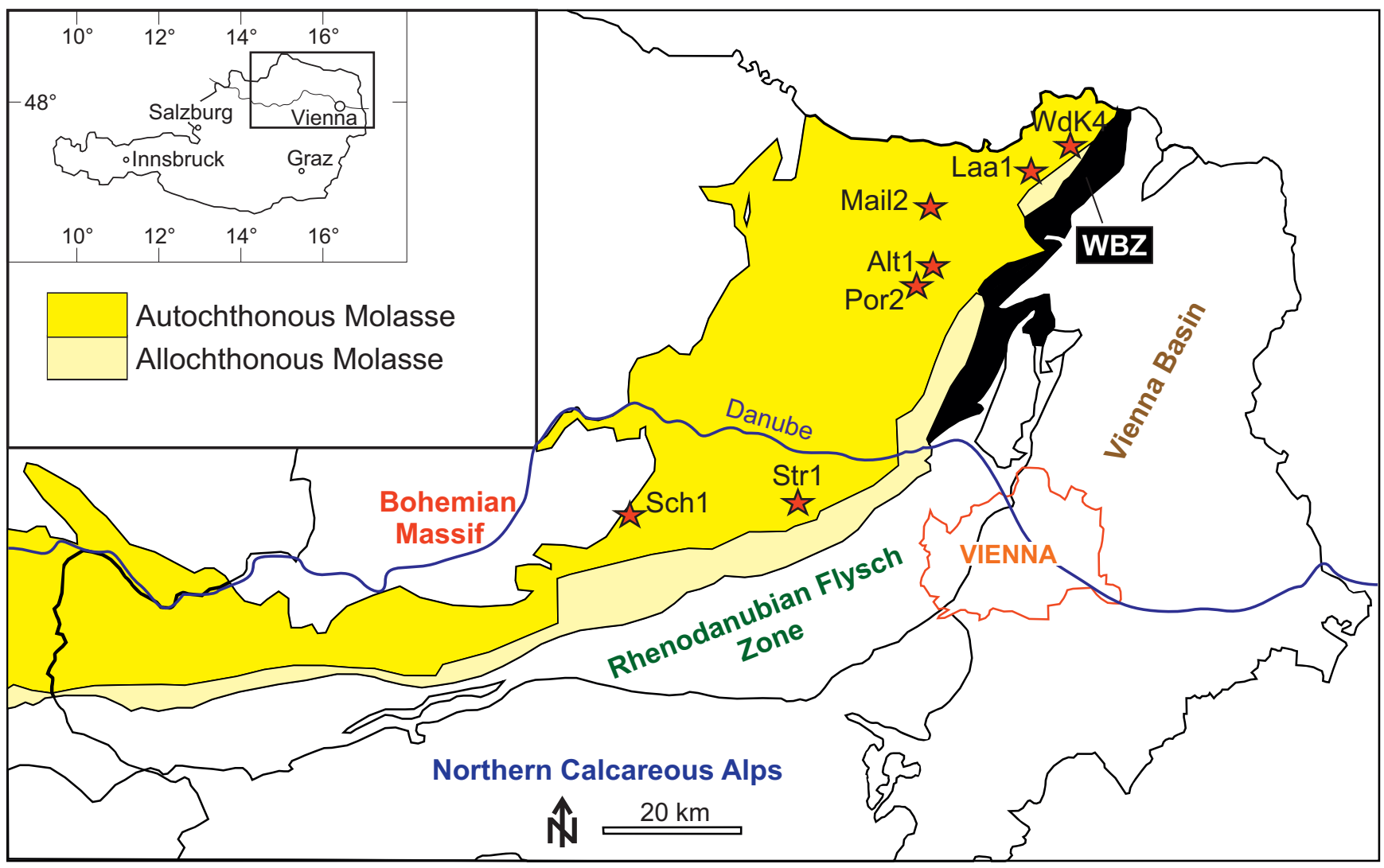

Figure 1: Overview geological map of the Lower Austrian Molasse Basin (modified from Wessely, 2006) and studied wells. Inset in upper left corner: Position of the study area in Austria. WBZ= Waschberg Zone; Wells: WdK4= Wildendürnbach K4, Laa1= Laa 1, Mail2= Mailberg 2, Alt1= Altenmarkt im Thale 1, Por2= Porrau 2, Str1= Streithofen 1, Sch1= Schaubing NÖ 03.

Bohemian Massif and the southern to southeastern margin is formed by the main overthrust of the Alpine orogenic front (Fig. 1). To the east and northeast, overthrusts of the Waschberg Unit and the Carpathian fold-and-thrust belt delimitate the LAMB. Cenozoic clastics fill the basin with a thickness up to $4500 \mathrm{~m}$. Parts of the Molasse basin fill extend underneath the overthrusted Alpine nappes (Wagner, 1998; Wessely, 2006). The LAMB formed part of the Central Paratethys sea (Rögl and Steininger, 1983). Due to relative sea-level changes, marine transgressions and regressions led to changing depositional environments from marine to brackish and non-marine (see Piller et al., 2007) including the Rzehakia Lake System (e.g. Harzhauser and Mandic, 2008) in the early Miocene and the Lake Pannon during the late Miocene (e.g. Harzhauser et al., 2018).

The LAMB is characterized by three main tectonic subunits from north to south. The autochthonous Molasse, the study area of this work, comprises mostly undisturbed, flat-lying sediments in front and underneath the Alpine-Carpathian orogen. The allochthonous and parautochthonous Molasse comprise the tectonically deformed and/or transported parts of the LAMB (Steininger et al., 1986; Steininger and Wessely, 2000). It is divided by the southern spur of the Bohemian Massif into a western and eastern part. Piller et al. (2004) subdivided this eastern part, the LAMB, into two parts north and south of the Danube river, according to the Austrian Stratigraphic Chart.
The oldest autochthonous Molasse sediments along the margins of the Bohemian Massif in Lower Austria are Oligocene in age (Fig. 2), from Kiscellian to lower Egerian (regional Central Paratethys stages, see Piller et al., 2007; Krijgsman and Piller, 2012) with limnic-terrestrial sandy sediments and later brackish marginal clays and silts which were deposited during the Oligocene transgression. They occur together with and are followed by the shallow marine coastal sands of the Linz-Melk Formation (Roetzel et al., 2013; Berka, 2015). These light yellow to white quartz sands, poor in carbonates and mica, are not only found around the southern margin of the Bohemian Massif (Krenmayr and Roetzel, 2000), but also below the Alpine orogenic front and further up north of the Danube in several boreholes of the study area (Wessely, 2006; Berka, 2015). However, as not all sands can definitely be attributed to the Linz-Melk Formation, and their age is often uncertain, the informal term Basal Sands (Palzer-Khomenko et al., 2018b) is used in this work for possible equivalents of the Linz-Melk Formation in the investigated wells (Fig. 2) and includes an upper part of bioturbated sands and sandstones that is transitional to overlying pelites in the study area.

In the Eggenburgian (Miocene, late Aquitanian to middle Burdigalian) the northward progression of the orogenic front further narrowed the Molasse Basin in its southern parts, while the basin in the northeast widened 


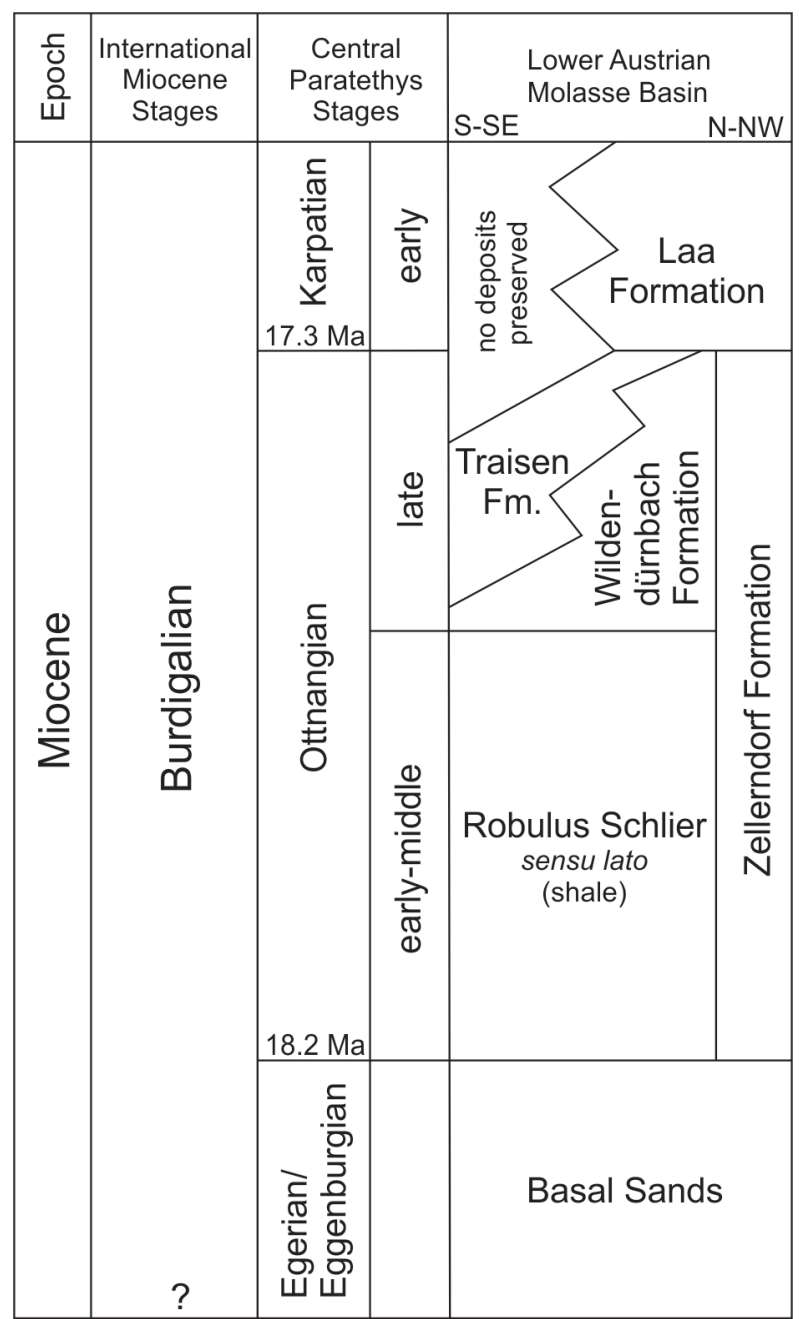

Figure 2: Stratigraphic overview modified from Palzer-Khomenko et al. (2018a). Fm. = Formation

due to transgressions onto the Bohemian Massif. A worldwide transgression led to the sedimentation of the marine marginal facies of the Eggenburg Group along the eastern margin of the Bohemian Massif north of the Danube (Berka, 2015; Roetzel, 2010), whereas south of the Danube, in the area of St. Pölten, the silty, basinal Hall Formation was deposited (Ćorić, 2017).

After a short regression, a new transgressive pulse started in the late Eggenburgian (middle Burdigalian). Nearshore sandstones (Zogelsdorf Formation) pass into the fully marine pelites of the transgressive Zellerndorf Formation in the upper Eggenburgian and lower Ottnangian successions (Roetzel et al., 2006; Berka, 2015). Diatomites (Limberg Member) are present. According to Palzer-Khomenko et al. (2018b), the calcite-free interval of the Zellerndorf Formation might represent partly the proximal continuation of the studied Wildendürnbach Formation (Fig. 2). South of the Danube, the transgression around the base of the Ottangnian (ca. 18.2 Ma) initiated the deposition of the fine grained, carbonate bearing "Robulus Schlier sensu lato" ("Jüngerer Schlier" of Piller et al., 2004) in an offshore marine setting (Roetzel et al., 2013). This lithostratigraphic unit represents a distal sublittoral facies occurring below the upper Ottnangian Traisen and Wildendürnbach formations. Palzer-Khomenko et al. (2018b) set the boundary between the Robulus Schlier and the Traisen Formation by the onset of a largely carbonate-free unit, the carbonate minimum interval (CMI).

In the late Ottnangian (late Burdigalian) brackish sedimentation started with the Traisen Formation (formerly Oncophora beds) south of the Danube, one part of the Pixendorf Group. According to Gebhardt et al. (2013), the Traisen Formation with its decalcified micaceous sands, silts and clays of the CMI represents a distal bypass facies to the proximal fan delta conglomerates of the Dietersdorf Formation. These formations comprise two interlinked parts of a bigger depositional system fed from the Alps and infilling a paleo-relief in the late Ottnangian. The Traisen Formation may reach up to several hundred meters in thickness in deeper parts of the studied basin area. The Traisen Formation was deposited in a brackish to freshwater sea (Rzehakia Lake System) during a global sea level lowstand, which separated the Paratethys from the Mediterranean Sea (Harzhauser and Mandic, 2008). Their higher kaolinite content in comparison to the underlying Robulus Schlier s.l. was interpreted as a consequence of shallowing of the basin by Gebhardt et al. (2013). Knierzinger et al. (2018) position the main source of the Traisen Formation sediments in the more internal, metamorphic Austroalpine basement units of the Eastern Alps. An endemic brackish to freshwater mollusc fauna with Limnopagetia and Rzehakia (formerly Oncophora) developed (Harzhauser and Mandic 2008, Corić, 2017) during this time interval. North of the Danube the time equivalent to the Traisen Formation is the Wildendürnbach Formation (Palzer-Khomenko et al., 2018b). It encompasses upper Ottnangian turbiditic and pelitic deposits in basinal central parts of the Rzehakia Lake System north of the Danube River. These orogen-derived sediments are poor in calcite and are part of the CMI together with the Traisen Formation, a distinct stratigraphic marker (Palzer-Khomenko et al., 2018a; 2018b).

In the Karpatian (uppermost Burdigalian) the marine mudrocks and sands of the Laa Formation were deposited north of the Danube (Fig. 2) as part of renewed major marine ingression from the southeast through the Vienna Basin and Waschberg Unit (Berka, 2015). These sediments mark the progression of the deepening of the basin towards the north-east, consisting of blue-grey and grey bedded and laminated clays and marls rich in mica with intercalations of sand layers and lenses (Wessely, 2006). In contrast to the underlying formations, the Laa Formation is again calcareous and bears fully marine fossils, thus this formation defines the termination of the CMI around the Ottnangian-Karpatian boundary at ca. 17.3 Ma (Palzer-Khomenko et al., 2018b).

The following marine transgressions in the early Badenian (Langhian, middle Miocene) once more reached wide parts of the Molasse basin, followed by erosion, and patchy distribution of Sarmatian brackish shallow marine sediments and fluvial to lacustrine deposits of Lake Pannon in the LAMB (Berka, 2015). 


\section{Methods}

The clay mineralogy of Miocene mudstones of OMV AG oil and gas exploration wells Wildendürnbach K4 (WDK4), Laa 1, Mailberg 2 (Mail2), Altenmarkt im Thale 1 (Alt1), Porrau 2 (Por2) and Streithofen 1 (Str1), and the water-well Schaubing NÖ 03 (Sch1) of the Lower Austrian Molasse Basin were characterized by analysing well core samples. The seven investigated wells are distributed across the LAMB from the northeast to the southwest (Fig. 1). Well Wildendürnbach K4 is located north of the river Danube near the border to the Czech Republic, followed by wells Laa 1, Mailberg 2, Altenmarkt im Thale 1 and Porrau 2 towards southeast. Wells Streithofen 1 and Schaubing NÖ 03 are located south of the Danube.

For clay analyses, 74 pelitic samples were selected (Table 1, Fig. 3). The sampling interval in well Schaubing was $10 \mathrm{~m}$, in Well Streithofen 1 it was 30 to $100 \mathrm{~m}$ and in well Wildendürnbach $\mathrm{K} 4$ it was $50 \mathrm{~m}$. In wells Laa 1, Mailberg 2, Altenmarkt im Thale 1 and Porrau less pelitic core material was available resulting in more irregular sampling intervals.

For clay mineral preparation, parts of the samples were crushed by hand to rock pieces of approximately 2 to $3 \mathrm{~mm}$. The samples were disaggregated with diluted $\mathrm{H}_{2} \mathrm{O}_{2}$ to remove the organic matter and afterwards treated for 3 min with a $400 \mathrm{~W}$ ultrasonic probe. The $<2 \mu \mathrm{m}$ fraction was separated by sedimentation in an Atterberg cylinder and dried at $50{ }^{\circ} \mathrm{C}$. The homogenised samples were then saturated with $\mathrm{K}^{+}$and $\mathrm{Mg}^{2+}$ ions and oriented samples were prepared by dispersing $10 \mathrm{mg}$ of clay in $1 \mathrm{ml}$ of water, pipetting the suspensions onto glass slides and drying at room temperature. The oriented, $\mathrm{K}$ - and $\mathrm{Mg}$ saturated samples were analysed in air-dried state and after vapour solvation with either ethylene glycol (KEG in Fig. 3A) or glycerol (MgGly) at $60^{\circ} \mathrm{C}$ for $24 \mathrm{~h}$ to identify expandable clay minerals like smectite, vermiculite and mixed-layer minerals. Additional K-saturated samples were heated to $550{ }^{\circ} \mathrm{C}$ to destroy kaolinite and expandable clay minerals (Moore and Reynolds, 1997).

The prepared clay samples were analysed with a Panalytical PW 3040/60X'Pert PRO diffractometer (CuKa radiation, $40 \mathrm{kV}, 40 \mathrm{~mA}$, step size $0.0167,5 \mathrm{~s}$ per step). The $\mathrm{X}$-ray patterns were interpreted according to Moore and Reynolds (1997). Smectite is identified by a broad peak at ca. $15 \AA$ with Mg saturation which shifts to $12 \AA$ with $\mathrm{K}$ saturation and collapses to $10 \AA$ after heating to $550^{\circ} \mathrm{C}$. Saturation of the K-sample with ethylene glycol expands smectite again to $17 \AA$, the Mg-sample with glycerol to $18 \AA$. Chlorite was identified by the peaks at $14 \AA$, $7 \AA$, $4.7 \AA$ and $3.53 \AA$ which do not change position during treatments. Illite peaks at $10 \AA ⿻ 5 \AA$ and $3.3 \AA$ also keep their positions. Kaolinite peaks at $7 \AA$ and $3.57 \AA$ disappear after heating to $550{ }^{\circ} \mathrm{C}$. Mg-saturated vermiculite has a strong peak at $14 \AA$, with $\mathrm{K}$ saturation it shifts to $10 \AA$. Ethylene glycol saturation of the K-sample or glycerol-saturation of the Mg-sample do not change their positions. The clay minerals were quantified with a modified version of the Schultz method (1964). The peak areas of the clay minerals in the $\mathrm{Mg}$ and glycerol saturated $\mathrm{x}$-ray patterns were determined using the Panalytical X'Pert Highscore plus software. The correction factors of Schultz (1964) which were originally used for the quantification of clay minerals in bulk samples were used to quantify the clay fraction. The correction factors are 0.35 for smectite, 0.54 for chlorite, 1 for illite, 0.5 for kaolinite, 0.35 for smectite and 0.37 for vermiculite.

Additionally, 10 samples of well Streithofen 1 were picked in intervals of approximately $50 \mathrm{~m}$ for the preparation of petrographic thin sections. The thin sections

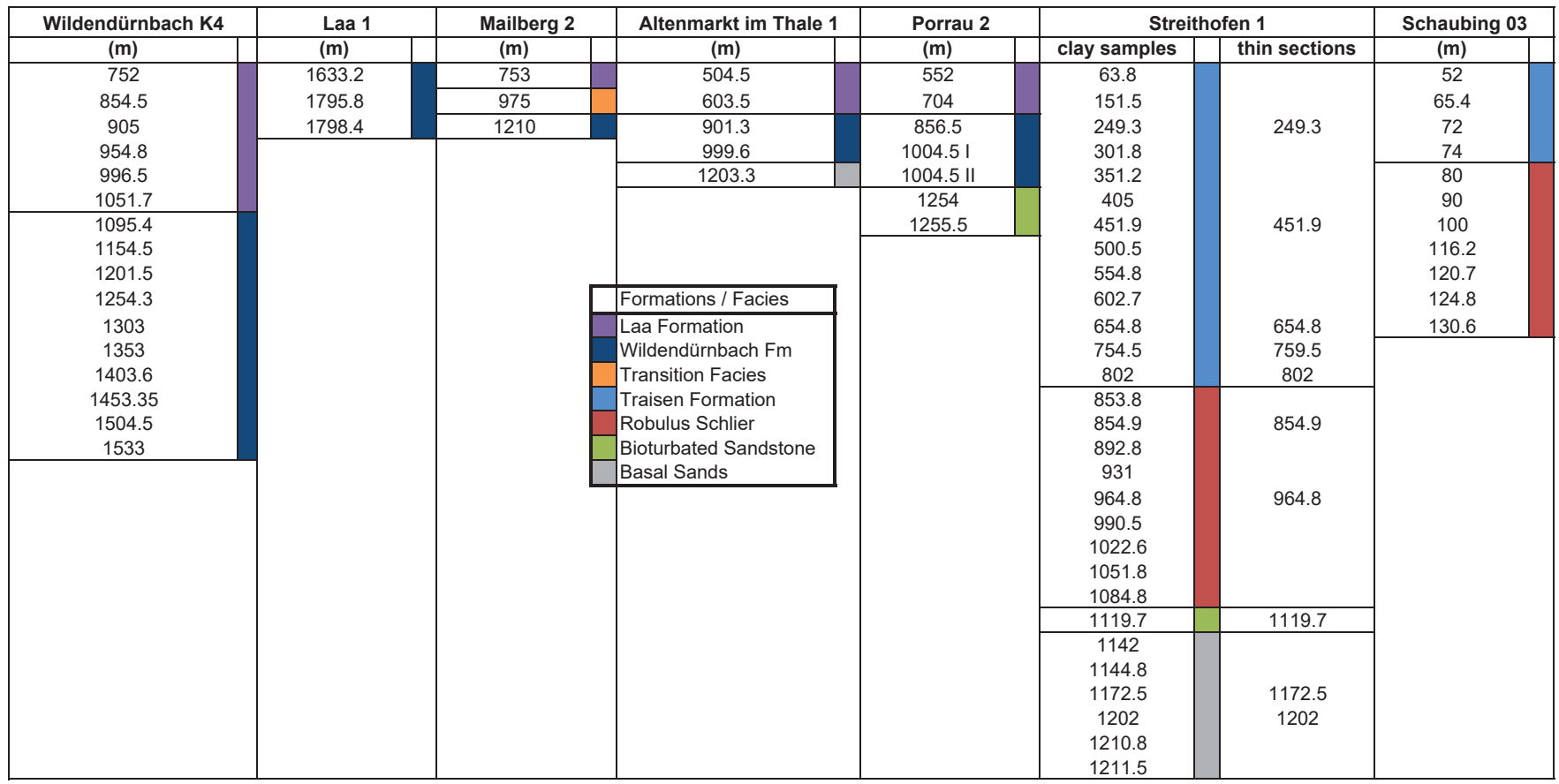

Table 1: Analysed clay mineral samples from wells Wildendürnbach K4, Laa 1, Mailberg 2, Altenmarkt im Thale 1, Porrau 2, Streithofen 1 and Schaubing 03. Depth in meters below surface. Formations and lithostratigraphic units are indicated with different colours. 

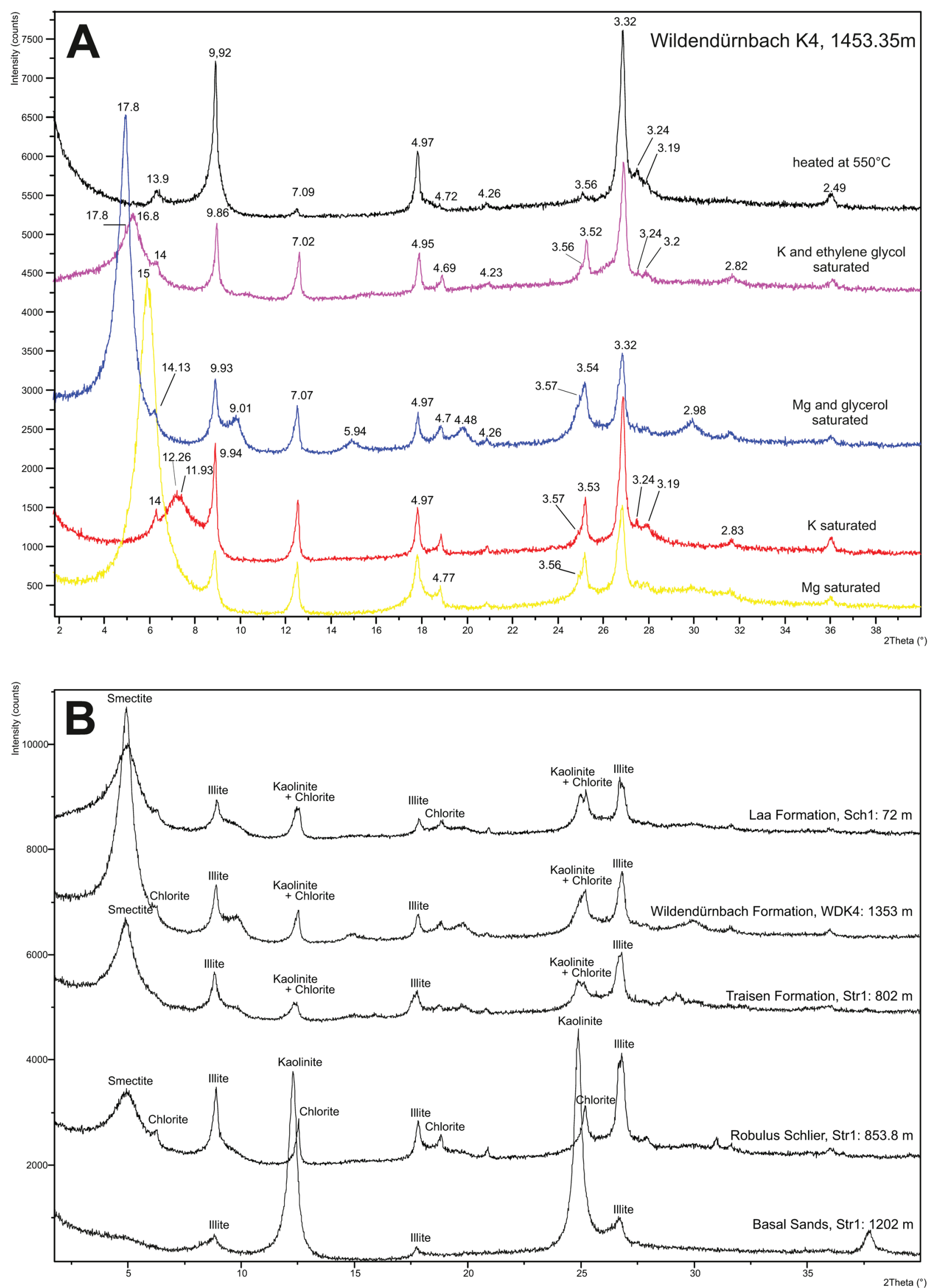

Figure 3: A) X-ray diffraction patterns of the clay fraction of sample $1453.35 \mathrm{~m}$ (Wildendürnbach $\mathrm{K} 4$ ), saturated with $\mathrm{Mg}, \mathrm{K}, \mathrm{Mg}$ and glycerol, $\mathrm{K}$ and ethylene glycol, and heated to $550^{\circ} \mathrm{C}$; d-values in Å. B) X-ray diffraction patterns of MgGly saturated representative samples of well Streithofen1: Basal Sands, Robulus Schlier, Traisen Fm., Wildendürnbach Fm., Laa Formation. 

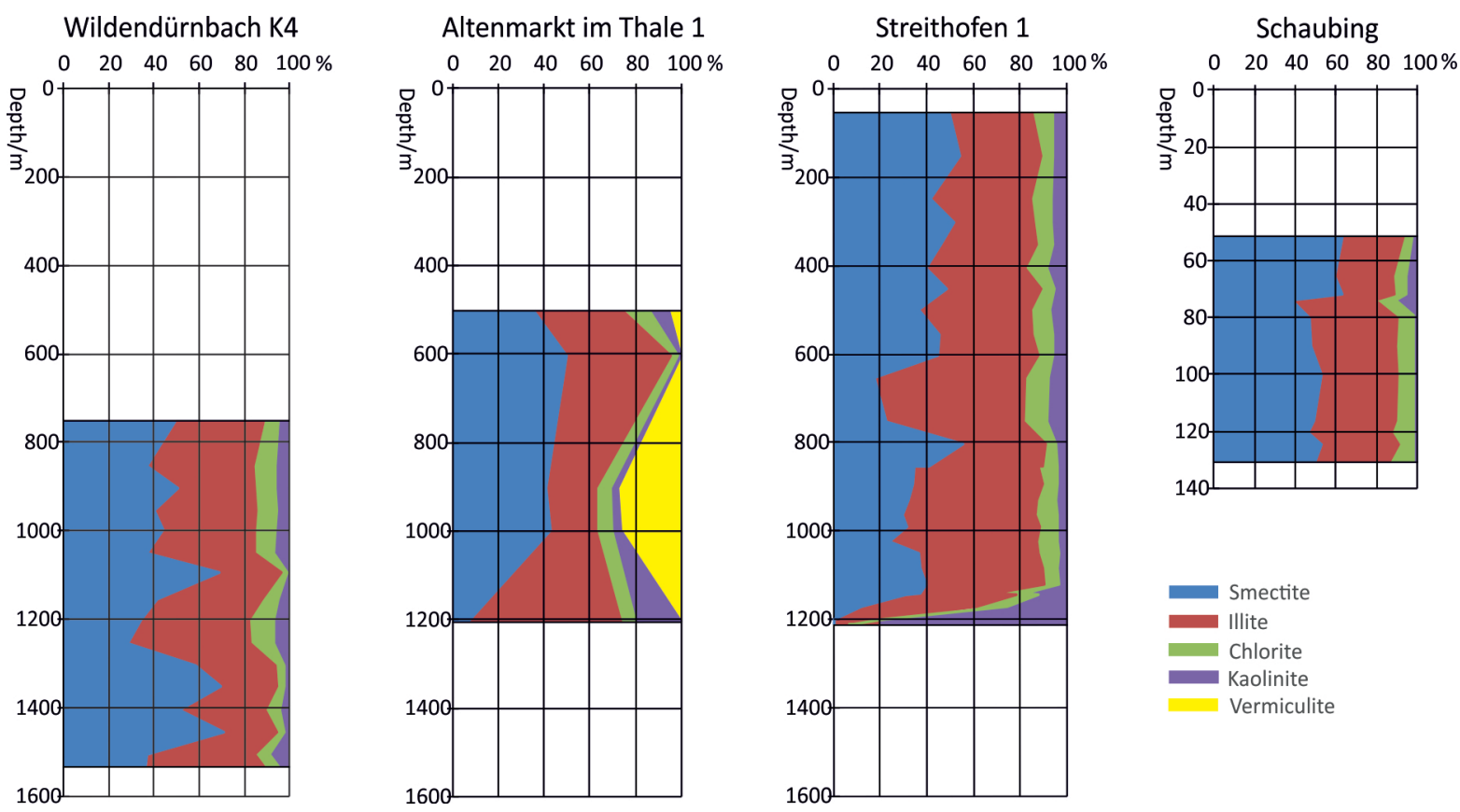

Figure 4: Overview of clay mineral content in sections from the wells Wildendürnbach K4, Altenmarkt i.T. 1, Streithofen 1 and Schaubing NÖ 03.

were stained by submerging half their area in an aqueous solution of Alizarin Red S, potassium ferricyanide (potassium hexacyanoferrate (III)) and hydrochloric acid for one minute (Dickson, 1966). The staining was carried out to differentiate between calcite and dolomite and their respective iron contents. Pictures of the thin sections were taken with a Leica DM2700 P microscope and the Leica Application Suite software.

\section{Results}

The results are described following the transect of wells, from southwest to northeast. Definitions of lithostratigraphic units for the wells are taken from Palzer-Khomenko et al. $(2018 \mathrm{a}, \mathrm{b})$.

\subsection{Well Schaubing 03}

The eleven pelitic samples of well Schaubing 03 cover a depth of 52 to $130.6 \mathrm{~m}$ below ground level (Fig. 4), mainly including the Traisen Formation at surface and the underlying Robulus Schlier. Smectite, illite, chlorite and kaolinite are the main clay minerals. The chlorite content lies between 4 and $13 \%$. The amount of illite reaches up to $43 \%$ and is at its lowest with $25 \%$. Only the uppermost samples of the Robulus Schlier above $74 \mathrm{~m}$ contain kaolinite. The kaolinite content rises from 3 to $10 \%$ at $74 \mathrm{~m}$ and then drops to zero in the samples at $80 \mathrm{~m}$ and below. The amount of smectite lies between 38 and $63 \%$.

\subsection{Well Streithofen 1}

The 29 samples of this well range from $53.8 \mathrm{~m}$ down to $1211.5 \mathrm{~m}$ below ground level (Fig. 4) and include the Traisen Formation, Robulus Schlier, bioturbated sandstones and Basal Sands (Palzer-Khomenko et al., 2018b). Smectite, illite, kaolinite and chlorite are present. Chlorite values range from 0 to $14 \%$. No chlorite could be identified in the lowermost three samples, which belong to the Basal Sands (Fig. 3B). Illite values vary between 7 and $65 \%$. The kaolinite content lies between 3 and $93 \%$, with the highest values in the deepest samples. Smectite reaches up to $55 \%$. In the lowermost three samples no smectite could be found.

Thin sections of 10 samples were prepared for well Streithofen 1. Generally, the samples are rich in organic matter and their colour ranges from grey-brown to brown. The grain size ranges from fine sand and silt to clay. Varying amounts of poorly to medium rounded quartz grains, feldspar, carbonate clasts, elongated mica grains, rounded glauconite grains and microfossils are surrounded by a fine-grained matrix of brownish colour.

In samples 451.9 and 969.8 (Traisen Formation and Robulus Schlier) lamination can be observed (see Fig. 5A, B). An opaque framboidal mineral, probably pyrite, is common and can often be found inside microfossils, mainly small foraminifers (Fig. 5A, C, D, E), or dispersed in the sediment. In sample 969.8 the pyrite enrichments follow the lamination. Organic matter and elongated mica grains are also aligned with the layering in most thin sections.

Carbonate grains are most frequent in samples from $853.8 \mathrm{~m}$ and below from the Robulus Schlier and the Basal Sands. The grains are mostly biogenic in origin, derived from small shell fragments and foraminifers (Fig. 5E). Euhedral crystals (Fig. 5F) might be of diagenetic origin. To distinguish between the different species of calcium carbonate and dolomite the thin sections were stained (Fig. 5D). In samples of the attributed to the Basal Sands, staining identified Fe-rich dolomitic cement in coarse grained quartz lenses at $1119.7 \mathrm{~m}$ and in sample 1172.5 finely dispersed Fe-rich dolomite was found throughout the matrix. 

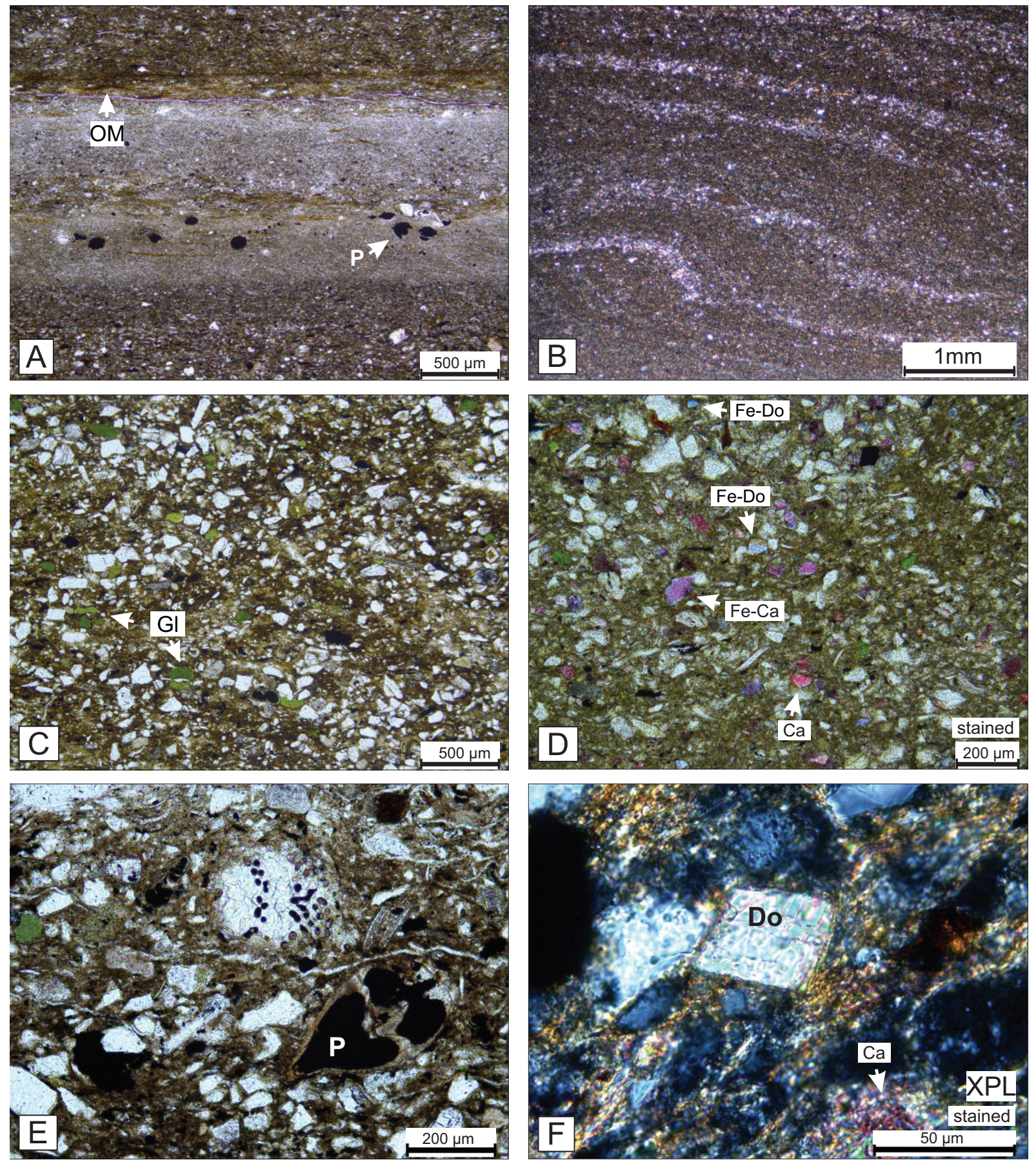

Figure 5: Thin-section photomicrographs of samples from well Streithofen 1 (A-E=plane polarized light (PPL). A) Sample 451.9. Lamination, pyrite framboids (P) and fillings, and high amounts of organic matter (OM). B) Sample 969.8. Deformed lamination. C) Sample 854.9. Abundant glauconite (Gl). D) Sample 1119.5. Fe-free calcite (Ca) is stained red, calcite with increased Fe-content /Fe-Ca) stained purple; Fe-free dolomite (Fe-Do) shows no staining and grades to light and dark blue with increasing Fe-content. E) Sample 854.9. Foraminiferal test filled with pyrite framboids (P). F) Sample 854.9. Euhedral dolomite crystal (Do) and minor calcite (Ca); crossed polarized light (XPL).

Bioturbation is visible in several samples, identifiable as dark, fine grained patches in samples 969.8 (Fig. 5B, Robulus Schlier) and 1119.7 (Fig. 5D, bioturbated sandstone). Coarse-grained lenses in 759.5 (Traisen Formation), 969.8 and 1172.5 (Basal Sands) may represent bioturbation or lenses of lenticular bedding.

In most thin sections glauconite granules can occasionally be found, especially in areas with coarser grain sizes. The highest amount of glauconite is found in sample 854.9
(Robulus Schlier) and in smaller amounts at $1119.7 \mathrm{~m}$ (bioturbated sandstones; Fig. 5C, D). The mineral grains occur as round green granules, some still spherical while others seem to be deformed.

\subsection{Well Wildendürnbach K4}

The 16 samples from well Wildendürnbach $\mathrm{K} 4$ reach from $752 \mathrm{~m}$ down to $1533 \mathrm{~m}$ depth below ground level (Fig. 4) and cover the Laa Formation and the Wildendürnbach 
Streithofen 1: Smectite/lllite

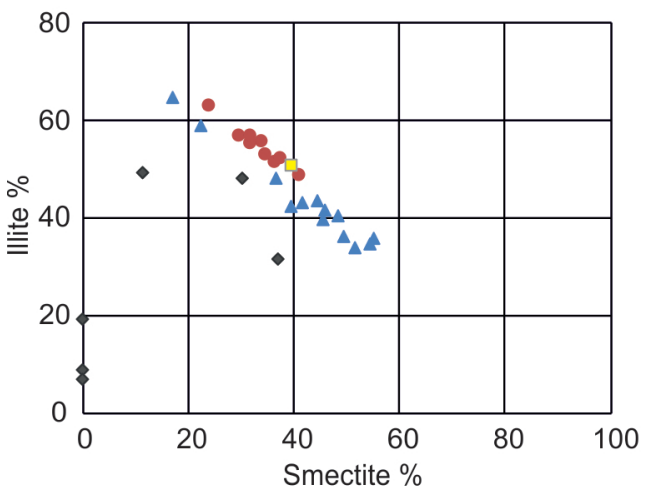

Kaolinite/lllite

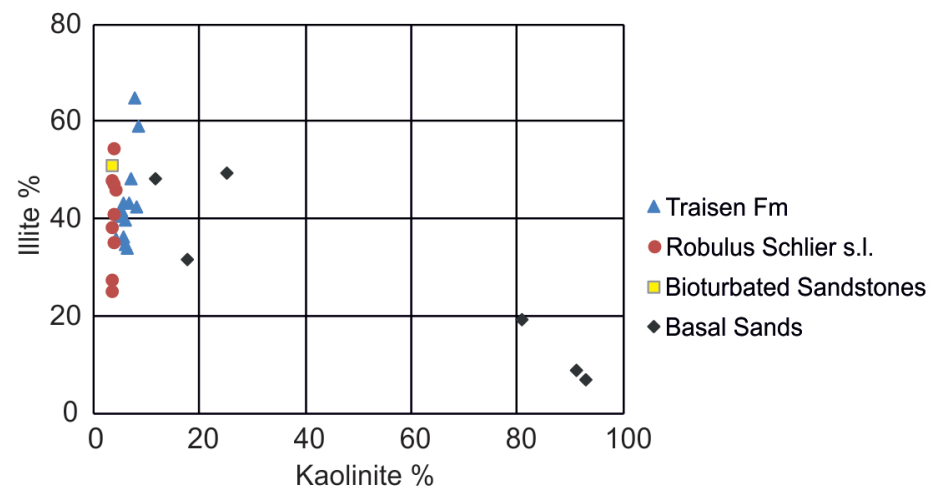

Figure 6: Clay mineral discrimination diagrams of the main formations regarding A) smectite versus illite, and B) kaolinite versus illite in well Streithofen 1.

Formation. The mineralogy is similar to the other wells. Chlorite ranges from 2 to $11 \%$ and kaolinite from 1 to $9 \%$. The amount of illite varies from 24 to $54 \%$. For smectite there is a big spread in the distribution of values from $28 \%$ up to $70 \%$.

\subsection{Wells Laa 1, Mailberg, Altenmarkt im Thale 1, Porrau 2}

In well Laa 1 only three samples at $1633.2,1795.8$ and $1798.4 \mathrm{~m}$ depth were suitable for clay mineral analyses, derived from the Wildendürnbach Formation. Smectite and illite were the main minerals, reaching up to 57 and $46 \%$, respectively. Chlorite and kaolinite contents stay well below $10 \%$.
In well Mailberg three samples at 753 m (Laa Formation), $975 \mathrm{~m}$ (Transition Fazies) and $1210 \mathrm{~m}$ (Wildendürnbach Formation, Palzer-Khomenko et al., 2018b) were investigated for clay mineralogy. Again, illite and smectite are the main minerals. Chlorite averages to $10 \%$ and kaolinite to $7 \%$. Vermiculite was observed in sample $975 \mathrm{~m}$ and reaches $15 \%$.

In well Altenmarkt im Thale 1 five samples were available (Fig. 4). In samples at $901.3 \mathrm{~m}$ and $999.6 \mathrm{~m}$ from the Wildendürnbach Formation vermiculite with amounts up to $28 \%$ was found. Smectite values start at $7 \%$ and reach up to $50 \%$. In the deepest sample from the Basal Sands at $1203.3 \mathrm{~m}$ the main minerals are kaolinite with $20 \%$ and illite with $67 \%$, while smectite reaches only $7 \%$.

\begin{tabular}{|c|c|c|c|c|c|c|c|c|c|}
\hline \multirow[b]{2}{*}{$\%$} & \multicolumn{2}{|c|}{ Wildendürnbach K4 } & \multirow{2}{*}{$\frac{\text { Laa } 1}{\text { WDF }}$} & \multicolumn{3}{|c|}{ Mailberg 2} & \multicolumn{3}{|c|}{ Altenmarkt i.T. 1} \\
\hline & LAAF & WDF & & LAAF & TFA & WDF & LAAF & WDF & BS \\
\hline Smectite & 43 & 50 & 48 & 49 & 46 & $\overline{24}$ & 43 & $\overline{42}$ & 7 \\
\hline Illite (mica) & 42 & 40 & 39 & 33 & 22 & 59 & 42 & 21 & 67 \\
\hline Chlorite & 9 & 6 & 7 & 11 & 10 & 10 & 7 & 7 & 6 \\
\hline Kaolinite & 6 & 5 & 6 & 7 & 8 & 7 & 5 & 4 & 20 \\
\hline Vermiculite & 0 & 0 & 0 & 0 & 15 & 0 & 3 & 27 & 0 \\
\hline
\end{tabular}

\begin{tabular}{|c|c|c|c|c|c|c|c|c|c|}
\hline \multirow[b]{2}{*}{$\%$} & \multicolumn{3}{|c|}{ Porrau 2} & \multicolumn{4}{|c|}{ Streithofen 1} & \multicolumn{2}{|c|}{ Schaubing 03} \\
\hline & LAAF & WDF & BBSS & $\mathrm{TF}$ & $\overline{\mathrm{RS}}$ & BBSS & $\overline{B S}$ & $\mathrm{TF}$ & $\mathrm{RS}$ \\
\hline Smectite & 46 & 61 & 43 & 43 & 33 & 40 & 13 & 56 & $\overline{49}$ \\
\hline Illite (mica) & 38 & 27 & 44 & 43 & 55 & 51 & 27 & 31 & 40 \\
\hline Chlorite & 10 & 8 & 9 & 8 & 8 & 6 & 6 & 7 & 11 \\
\hline Kaolinite & 6 & 5 & 4 & 6 & 4 & 3 & 53 & 6 & 0 \\
\hline Vermiculite & 0 & 0 & 0 & 0 & 0 & 0 & 0 & 0 & 0 \\
\hline
\end{tabular}

\begin{tabular}{|r|c|c|c|l|}
\hline Formations & Age & facies & calcareous mudstones, sands & main clay minerals \\
\hline LAAF & Karpatian & marine & $\mathrm{cl}, \mathrm{kao}$ \\
WDF & upper Ottnangian & brackish & shale, silty mudrocks, micaceous sands & $\mathrm{sm}, \mathrm{il}, \mathrm{cl}, \mathrm{kao}, \mathrm{v})$ \\
TF & upper Ottnangian & brackish & silty mudrocks, micaceous sands & $\mathrm{sm}, \mathrm{il}, \mathrm{cl}, \mathrm{kao}$ \\
RS & lower Ottnangian & marine & calcareous mudstones to marls, sands & il, sm, cl \\
BS & Egerian to Eggenb. & (fluviatile) & coaly shale, silty mudrocks, sands & $\mathrm{kao}, \mathrm{il}, \mathrm{sm}, \mathrm{cl}$ \\
\hline
\end{tabular}

Table 2: Overview of wells and average clay mineral content (in \%) of the $<2 \mu \mathrm{m}$ fractions in the different lithostratigraphic units of the LAMB. LAAF. $=$ Laa Formation, WDF $=$ Wildendürnbach Formation, TFA $=$ Transition Facies, BS = Basal Sands, BBSS $=$ bioturbated sandstones, TF $=$ Traisen Formation, $\mathrm{RS}=$ Robulus Schlier. Clay minerals: $\mathrm{sm}=$ smectite, il = illite, $\mathrm{cl}=$ chlorite, $\mathrm{kao}=$ kaolinite, $\mathrm{v}=$ vermiculite . 


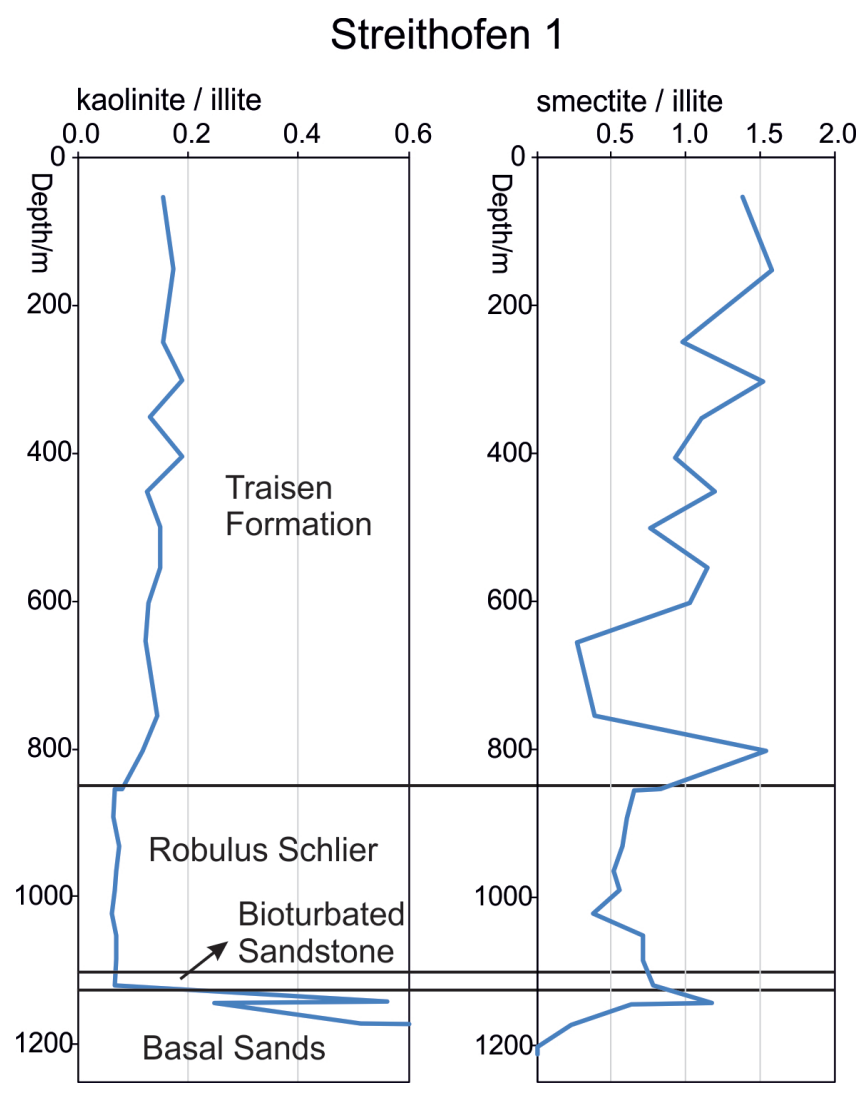

Figure 7: Trends in clay mineral ratios in well Streithofen 1. A) Kaolinite/ illite ratio, cut at 0.6 . for reasons of visualisation. B) Smectite/ illite ratio. Formation boundaries in well Streithofen 1 from Palzer-Khomenko et al. (2018a, b).

In well Porrau2 seven samples between 552 and $1255.5 \mathrm{~m}$ depth were analysed, including the Laa Formation, the Wildendürnbach Formation and bioturbated sandstones. The chlorite content lies between 6 and 14\% and illite content between 25 and $51 \%$. Kaolinite ranges from 2 to $9 \%$. Smectite values start at $29 \%$ and reach up to $64 \%$.

\section{Discussion}

\subsection{Stratigraphic implications}

In most of the studied wells, clay mineralogy (Table 2) can help to distinguish the different formations as defined by Palzer-Khomenko et al. (2018a, b). In wells Schaubing 03 and Streithofen 1, the Traisen Formation, the Robulus Schlier and the Basal Sands can be differentiated by higher variability in the smectite/illite ratios (Fig. 6A) and their respective kaolinite contents (Fig. 6B). The Robulus Schlier contains no or insignificant amounts of kaolinite, whereas the kaolinite content in the Traisen Formation can range up to $10 \%$ and in the Basal Sands kaolinite is the main clay mineral reaching up to $93 \%$. Lack of kaolinite in the Robulus Schlier was already described in Gebhardt et al. (2013) and Wimmer-Frey et al. (2013).

Looking at the kaolinite/illite ratios (Fig. 7A) in the studied stratigraphic interval of well Streithofen, the ratios of the Basal Sands reflect their high kaolinite content, while the Robulus Schlier shows stable values lower than the other formations. In the Traisen Formation, kaolinite/illite ratios slightly increase upwards the cores. Concerning smectite/illite ratios (Fig. 7B), the Robulus Schlier mostly shows distinct lower values than the overlying Traisen Formation. The amounts of illite and smectite behave inversely proportional in most samples. Generally, the Robulus Schlier demonstrates higher illite contents within the respective wells than the Traisen Formation, Basal Sands and Wildendürnbach Formation. The Wildendürnbach Formation can reach very high smectite contents, but the values are much wider spread than in the other formations. The Laa Formation comprises more moderate smectite and illite values.

In well Altenmarkt im Thale 1 the sample at $1203.3 \mathrm{~m}$ contains less smectite (7\%) and higher illite (67\%) and kaolinite (20\%) content than the samples directly above. Because of its position close to the underlying Mesozoic carbonates starting at approximately $1205 \mathrm{~m}$ and clay mineral values similar to those of the Basal Sands encountered in well Streithofen 1, we place this unit into the group of Basal Sands. This part was interpreted as a paleosurface which was transgressed by lower Ottnangian or Eggenburgian bioturbated sandstones.

Also, the high smectite contents and increased smectite/illite ratios in wells WDK4, Schaubing 03 and Streithofen 1 coincide with low carbonate values of the carbonate minimum zone as described in Palzer-Khomenko (2018a, b).

\subsection{Palaeoclimate and provenance according to clay mineralogy}

\subsubsection{Smectite}

The clay mineralogy samples of well Wildendürnbach K4 comprise two formations according to Palzer-Khomenko (2018a, b), namely the Karpatian Laa Formation down to sample 1051.7, followed downhole by the upper Ottnangian Wildendürnbach Formation down to the deepest sample at $1533 \mathrm{~m}$. The upper part shows very little variation in clay minerals, with smectite averaging to $43 \%$ and illite to $42 \%$, but in the Wildendürnbach Formation samples with peak smectite contents up to $70 \%$ can be identified (Fig. 4). Smectites may be generally derived from weathering in warm to temperate climate characterized by alternating humid and dry seasons, resulting in humid or sub-arid to arid weathering processes. For example, smectites can form in tropical climates with contrasted seasons characterized by long dry periods, covering rocks rich in $\mathrm{Ca}^{2+}$ and $\mathrm{Mg}^{2+}$ like basalts, shales, limestones and volcanic ashes (Meunier, 2005). However, peak smectite values may point to volcanic input or reworking of older smectite-bearing sedimentary rocks (Chamley, 1989).

According to Palzer-Khomenko et al. (2018a, b), the Wildendürnbach Formation comprises an equivalent to both the Traisen Formation and parts of the Zellerndorf Formation. Within the more marginal Zellerndorf Formation, episodes of volcanic input during the Ottnangian 
and Karpatian were described by Roetzel and Reháková (1991), Nehyba and Roetzel (1999) and Roetzel et al. (2015). Consequently, volcanic input and the subsequent alteration of volcanic ash could account for the high smectite amounts in the WDK4 samples at 1095.4, 1353 and $1453.35 \mathrm{~m}$ (Fig. 3).

\subsubsection{Kaolinite}

The decreased kaolinite contents in the Robulus Schlier s.l. (lower/middle Ottnangian) of wells Streithofen 1 and Schaubing could indicate a cooler climate compared to the overlying Traisen Formation. Alternatively, the higher kaolinite content of the Traisen Formation was interpreted as a result of the shallowing of the basin and grain sorting effects (Gebhardt et al., 2013). The stratigraphic position within the Burdigalian and the clay mineral assemblage with low kaolinite contents suggests a correlation to relatively cooler early Miocene climate phases before the Mid-Miocene Climate Optimum (MMCO, e.g. Gradstein et al., 2012).

The nearby Bohemian Massif could have been a likely source for the high kaolinite values (Figs. 4, 7) encountered in the deepest samples of wells Streithofen 1 and Altenmarkt im Thale 1. Chemical alteration of feldspar-rich granites, granulites, arkoses, sandstones and conglomerates led to the formation of kaolinite deposits (e.g. Werneck, 1980; Menzl, 1988; Weber, 1997; Migoñ, 2003; Höhn et al., 2014) on exposed surfaces of the Bohemian Massif. Different causes and ages of kaolinitization on the Bohemian Massif were put forward, going back as far as the Cretaceous (Migoñ, 2003). Intense chemical weathering in hot and humid climates occurred also in the Eocene (Steininger and Roetzel, 1999). Therefore, the high kaolinite contents found in the Basal Sands of well Streithofen 1 might be related to long-term soil formation and weathering products of the Bohemian Massif and may not correlate directly to a warm-humid climate phase during deposition. Correlation of the Basal Sands with the Linz Melk Formation indicates a Kiscellian to Egerian age (Oligocene to earliest Miocene), but no direct palaeoclimatic correlation can be interpreted because of the loose time constraints of this lithofacies unit.

However, these Basal Sands with their kaolinite-predominance give a clear provenance signal for sources in the Bohemian Massif and thus an orogen-external source in the early foreland phase. Source rocks may comprise granulites of the Bohemian Massif which directly underlie the Basal Sands in well Streithofen 1; alternatively, they may be derived from weathered outcrops of rocks of the Bohemian Massif at some distance. A similar phenomenon was described by Gier $(1998,2000)$ from the North Alpine Foreland Basin of Upper Austria, the western continuation of the LAMB, based on the evolution of clay minerals in two hydrocarbon exploration wells (Puchkirchen and Geretsberg). The investigated samples in Gier $(1998,2000)$ are slightly older (early Oligocene to early Miocene) than the samples in this study. Also, in Upper Austria, an increase of kaolinite with depth was observed - a trend not common during diagenesis (Hower et al., 1976). Similar to the studied sections in the $\mathrm{LAMB}$, weathering products from crystalline basement rocks of the Bohemian Massif led to an increase of kaolinite with depth in the Upper Austrian Molasse successions.

\subsubsection{Illite and chlorite}

Illite and chlorite may be principally derived from physical weathering of various source rocks or from illitization and chloritization of smectite (or kaolinite) during burial diagenesis (Chamley, 1989). This implies that a diagenetic overprint could distort the palaeoclimate and provenance signals. However, in the investigated sections, the illite content varies irregularly with depth and no clear diagenetic trend can be identified. Some smectites from shallow depths contain around $20 \%$ illite, but because of the low temperature, these randomly interstratified mixed layer minerals must be inherited. In none of the samples ordered illite/smectite mixed layer minerals (smectite with more than $50 \%$ illite) were found. Therefore, illite can be attributed to primary detrital input, likely related to the exhumation and uplift of the Alps which led to increased physical weathering. Knierzinger et al. (2018) suggest mainly Austroalpine crystalline rocks from the Eastern Alps as source for the sandy material of the Traisen Formation, and some additional influence from the Bohemian Massif for northern parts of the study area. Thus, illite predominance derived from denudation of the rising Eastern Alps and the exhumed and weathered Austroalpine basement rocks conforms with the southern provenance of the upper lithostratigraphic units of the LAMB.

Chlorite is mainly a detrital mineral and can be derived through physical weathering of crystalline igneous or metamorphic rocks and can also form through alteration of some volcanic rocks (Chamley, 1989). In the studied samples chlorite roughly follows the illite trends, which suggests a related source of low-metamorphic Alpine (Austroalpine) rocks (Knierzinger et al., 2018).

\subsubsection{Vermiculite}

The Wildendürnbach Formation (samples $901.3 \mathrm{~m}$ and $999.6 \mathrm{~m}$ ) in well Altenmarkt im Thale 1 shows high vermiculite content of up to $27 \%$ (Fig.4) and sample 975 in well Mailberg (Transition Facies) reaches 15\% vermiculite. The occurrence of vermiculites could indicate a higher input of temperate climate soils (Chamley, 1989), increased input of weathered biotite from granites or weathered chlorite (Meunier, 2005). Heavy mineral associations discussed in Knierzinger et al. (2018) relate the Ottnangian and Karpatian sands in the area of Mailberg and Porrau with a slightly stronger influence of Moldanubian and Moravian metapelitic rocks from the Bohemian Massif compared to the Traisen Formation. As well Altenmarkt im Thale 1 is close to wells Porrau 2 and Mailberg 2, this could explain the high vermiculite content in some samples. 


\begin{tabular}{|c|c|c|c|c|}
\hline & & & $\begin{array}{lr}\text { SE (internal) } & \text { NW (external) } \\
\text { Eastern Alps } & \text { Bohemian Massif }\end{array}$ & \\
\hline \multirow{4}{*}{ 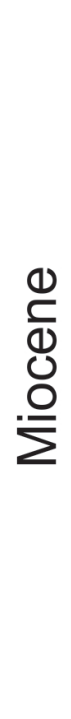 } & \multirow{4}{*}{ 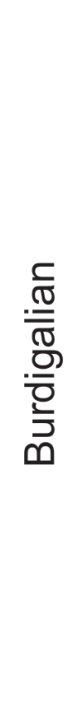 } & 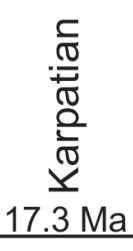 & 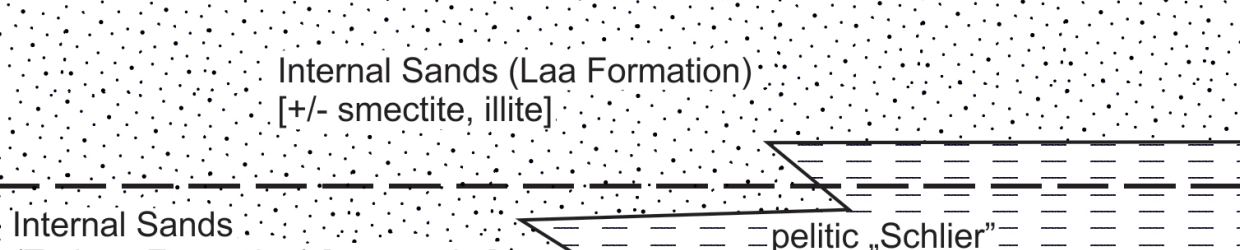 & \\
\hline & & \multirow{2}{*}{ 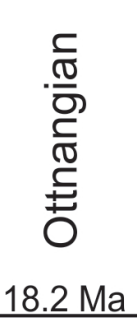 } & 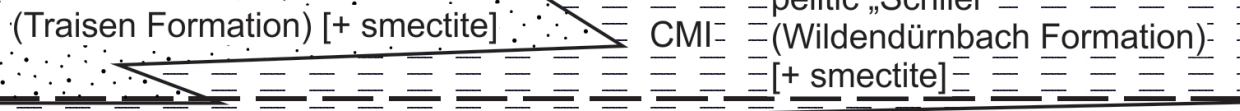 & $\mathrm{CMI}$ \\
\hline & & & 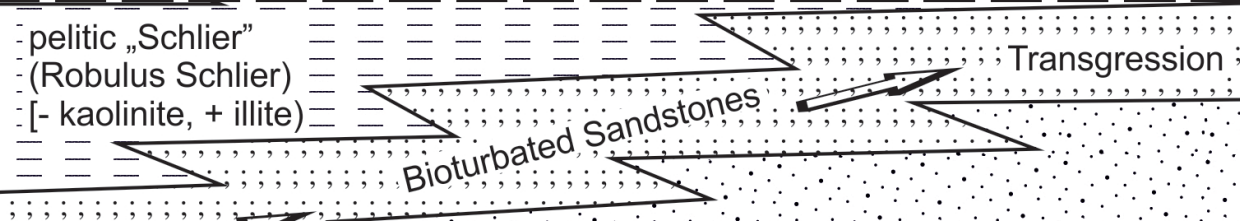 & \\
\hline & & $\begin{array}{l}\text { Eggen- } \\
\text { burgian/ } \\
\text { Egerian? }\end{array}$ & and (Basal Sands) [+ kaolinite] & \\
\hline
\end{tabular}

Figure 8: Schematic foreland facies model for the northward shifting LAMB deposition, including clay mineral evolution (lithology patterns: dotted = sandy, dashed = claystones, colons = clayey sands). While the lithological facies grade from SE to NW due to foreland thrusting, the CMI (carbonate minimum interval) provides a synchronous event around the Ottnangian-Karpatian boundary crosscutting the facies borders (Palzer-Khomenko et al., 2018a).

\subsubsection{Glauconite}

Some thin sections of the Robulus Schlier (sample 854.9, Fig.5C) and the underlying bioturbated sandstones (sample 1119.7, Fig.5D) of well Streithofen 1 are rich in glauconite, while the samples of the Traisen Formation show a lesser abundance. According to Meunier (2005) recent glauconite granules are most abundant in the intertropical domain between $125 \mathrm{~m}$ and $250 \mathrm{~m}$ water depth and require an open marine environment with a low terrigenous sedimentation rate, Fe- and K-supply, and sufficient organic matter for their neoformation through substitution of minerals or planktonic shells. Due to the reducing properties of the organic matter during glauconitisation, they are often associated with pyrite.

Thus, glauconite may be an additional hint to a warmer palaeoclimate phase during the deposition of the bioturbated sandstones and parts of the Robulus Schlier, with lowered terrigenous input due to increased chemical weathering. However, kaolinite is lacking in comparison to the other formations and the Traisen Formation still shows occasional glauconite grains in the thin-section.

\subsection{Palaeogeographic implications}

In general, the clay minerals trace the palaeogeographic and provenance evolution of a typical foreland basin (e.g. Sinclair, 1997) in the area of the LAMB (Fig. 8). During the initial basin stage (Egerian-Eggenburgian), with the beginning of northward shifting foreland basin subsidence and peripheral bulge formation, external (northern) sources from the Bohemian Massif prevailed in the study area, with erosion of longer-term weathered soils containing kaolinite as the predominant clay mineral as also evidenced by the occurrence of kaolinite deposits in this source area (Migoñ, 2003; Höhn et al., 2014). Continuing subsidence due to orogenic loading leads to increasing basin water depth and an evolution from more distal pelitic (i.e. Robulus Schlier) to more proximal sandy (i.e. Traisen Formation, Wildendürnbach Formation, Laa Formation) deposits of Alpine (southern) provenance. Illite predominates the Alpine provenance, characterized by fast uplift and denudation. However, admixture from other, non-Alpine sources may influence the ratios of illite to the other clay minerals such as smectite and kaolinite.

The position of well Wildendürnbach K4 in the North of the LAMB and its closeness to South Moravia, as well as the deep-water, turbiditic character of the Wildendürnbach Formation, make it possible that volcanic ash falls were mixed with other alpine-derived sediments. Thus, these high smectite contents may be due to volcanic admixture, although the extreme smectite amounts up to pure smectitic clays reported from some deposits along the margins of the Bohemian Massif (e.g. Nehyba and Roetzel, 1999) were not reached. Assuming the Traisen Formation in well Streithofen 1 was deposited at around the same time as the Wildendürnbach Formation in well WDK4 (Palzer-Khomenko et al., 2018b), the distal volcanic fallout could likewise influence the smectite values there. Still, the deposits of the Traisen Formation in well Streithofen 1 show overall lower smectite percentages than the Wildendürnbach Formation, which could be caused by even further dilution through the reported high sediment input and thus higher sedimentation rate from the southern clastic input centre (Palzer-Khomenko, et al., 2018b). Possible sources of these volcanic ash 
layers can be inferred from the Carpathian volcanic arc (e.g. Roetzel and Reháková, 1991; Roetzel et al., 2014) and the Pannonian Basin (Lukács et al., 2018). Other possible reasons for the differences in smectite content are a mix of different source areas, or differentiation through particle size during transport, causing fine grained smectites to be transported further into the basin than other minerals, which might result in higher smectite values in the more basinal Wildendürnbach Formation compared to the more proximal Traisen Formation.

During the timespan of the brackish Rzehakia Lake System (late Ottnangian), the Traisen and Wildendürnbach formations were deposited related to a global sea level lowstand, which separated the Paratethys from the Mediterranean Sea (Harzhauser and Mandic, 2008) and which led to a rather restricted basin system with increased volcanic influence (Palzer-Khomenko et al., 2018b). Kovac et al. (2018) reconstruct the Rzehakia Lake System as an important marker horizon due to the regression of the Ottnangian sea and terminated by the following fully marine transgression in the Karpatian, represented by the Karpatian Laa Formation in the LAMB area. Despite changes in palaeogeography and provenance due to the formation of the Vienna Basin (Palzer-Khomenko et al., 2018b), generally increasing smectite versus illite may point to a warming climate and increasing chemical weathering of the rising Alpine orogen.

\section{Conclusions}

- The clay mineralogy of the investigated wells is largely similar, consisting mainly of illite and smectite with smaller amounts of chlorite and kaolinite. Vermiculite occurs in a few samples in wells Altenmarkt im Thale 1 and Laa 1. This indicates in general both chemical and physical weathering in the source areas.

- The results of the clay mineral analyses allow correlation with recently proposed formation boundaries. In wells Schaubing 03 and Streithofen 1, the sediments of the Traisen Formation have higher kaolinite and smectite contents than underlying Robulus Schlier. Also, the Robulus Schlier shows a higher illite content than the Traisen Formation, Basal Sands and Wildendürnbach Formation. This difference can also be seen in smectite/illite and kaolinite/illite ratios.

- Highly increased kaolinite contents up to $93 \%$ separate the Basal Sands from the Robulus Schlier. In wells Altenmarkt im Thale 1 and Streithofen 1 this might be related to weathering products of the nearby Bohemian Massif or granulites of the underlying Bohemian Massif.

- In well Wildendürnbach K4, peak smectite contents of up to $70 \%$ in parts of the Wildendürnbach Formation can be explained by volcanic ash input with a source in the nearby Carpathian volcanic arc.

- The clay minerals trace the general palaeogeographic and provenance evolution of a typical foreland basin, from basal orogen-external sources, the strongly weathered Bohemian Massif characterized by kaolinite-predominance, to internal sources from the rising Alpine orogen, characterized mainly by illite and some chlorite.

\section{Acknowledgements}

This study is based on a Master thesis at the University of Vienna (Meszar, 2018). We would like to thank OMV E \& P for funding in the course of a University of Vienna-OMV cooperation project (grant number FA536022) and for providing the investigated drill cores and archive data, as well as the Geological Survey of Austria for providing the drill core of Schaubing NÖ 03. We thank both reviewers for their constructive remarks.

\section{References}

Berka, R., 2015. Zur Geologie der großen Beckengebiete des Ostalpenraumes. Abhandlungen der Geologischen Bundesanstalt, 64, 71-141.

Chamley, H., 1989. Clay Sedimentology. Springer-Verlag Berlin Heidelberg, XX+623 pp. http://dx.doi. org/10.1007/978-3-642-85916-8

Ćorić, S., 2017. 3.5. Molasse. In: Erläuterungen zur Geologischen Karte der Republik Österreich 1:50.000 Blatt 56 St. Pölten, Geologische Bundesanstalt, Wien, pp. 33-34.

Dickson, J.A., 1966. Carbonate identification and genesis as revealed by staining. Journal of Sedimentary Petrology, 36, 491-505. https://doi.org/10.1306/74D714F62B21-11D7-8648000102C1865D

Gebhardt, H., Ćorić, S., Krenmayr, H.-G., Steininger, H., Schweigl, J., 2013. Neudefinition von lithostratigraphischen Einheiten des oberen Ottnangium (Unter-Miozän) in der alpin-karpatischen Vortiefe Niederösterreichs: Pixendorf-Gruppe, Traisen-Formation und Dietersdorf-Formation. Jahrbuch der Geologischen Bundesanstalt, 153, 15-32.

Gier, S., 1998. Burial diagenetic processes and clay mineral formation in the Molasse Zone of Upper Austria. Clays and Clay Minerals, 46, 658-669.

Gier, S., 2000. Clay mineral- and organic diagenesis of the Lower Oligocene Schöneck Fishshale, western Austrian Molasse Basin. Clay Minerals, 35, 709-717.

Gradstein, F.M., Ogg, J.G., Schmitz, M.D., Ogg, G.M., 2012. The Geologic Time Scale 2012. Elsevier B V. https://doi. org/10.1016/C2011-1-08249-8.

Harzhauser, M., Mandic, O., 2008. Neogene lake systems of Central and South-Eastern Europe: Faunal diversity, gradients and interrelations. Palaeogeography, Palaeoclimatology, Palaeoecology, 260, 417-434. https://doi. org/10.1016/j.palaeo.2007.12.013

Harzhauser, M., Mandic, O., Kranner, M., Lukeneder, P., Kern, A.A., Gross, M., Carnevale, G., Jawecki, C., 2018. The Sarmatian/Pannonian boundary at the western margin of the Vienna Basin (City of Vienna, Austria). Austrian Journal of Earth Sciences, 111/1, 1-26. https://doi. org/10.17738/ajes.2018.0003 
Höhn, S., Frimmel, H.E., Pašava, J., 2014. The rare earth element potential of kaolin deposits in the Bohemian Massif (Czech Republic, Austria). Mineralium Deposita, 49/8, 967-986. https://doi.org/10.1007/s00126-014-0542-3

Hower, J., Eslinger, E.V., Hower, M.E.. Perry, E.A., 1976. Mechanism of burial metamorphism of argillaceous sediment: 1. Mineralogical and chemical evidence. Geological Society of America Bulletin, 87, 725-737.

Knierzinger, W., Wagreich, M., Palzer-Khomenko, M., Gier, S., Meszar, M., Lee, E.Y., Koukal, V., Strauss, P., 2018. Provenance and palaeogeographic evolution of Lower Miocene sediments in the eastern North Alpine Foreland Basin. Swiss Journal of Geosciences, 112, 269-286. https://doi. org/10.1007/s00015-018-0312-9

Knierzinger, W., Wagreich, M., Kiraly, F., Lee, E.Y., Ntaflos, T., 2019. TETGAR_C: a novel three-dimensional (3D) provenance plot and calculation tool for detrital garnets. Journal of Geosciences, 64, 127-148. https://doi.org/10.3190/ jgeosci.284

Kováč, M., Hudáčková, N., Halásová, E., Kováčová, M., Holcová, K., Oszczypko-Clowes, M., Báldi, K., Less, G., Nagymarosy, A., Ruman, A., Klučiar, T., Jamrich, M., 2017. The Central Paratethys palaeoceanography: a water circulation model based on microfossil proxies, climate, and changes of depositional environment. Acta Geologica Slovaca, 9/2, 75-114.

Kováč, M., Halásová, E., Hudáčková, N., Holcová, K., Hyžný, M., Jamrich, M., Ruman, A., 2018. Towards better correlation of the Central Paratethys regional time scale with the standard geological time scale of the Miocene Epoch. Geologica Carpathica, 69/3, 283-300. https://doi. org/10.1515/geoca-2018-0017

Krenmayr, H.-G., Roetzel, R., 2000. Die lithostratigraphische Formalisierung der Melker- und Linzer Sande: Die «Linz-Melk-Formation». Berichte des Institutes für Erdwissenschaften der Karl-Franzens-Universität Graz, 2, 10.

Krijgsman, W., Piller, W.E., 2012. Regional Stages; Central and Eastern Paratethys. In: Gradstein F.M., Ogg J.G., Schmitz M.D. \& Ogg G.M. (eds.), The geologic time scale 2012. Elsevier, Oxford, United Kingdom, pp. 935-937.

Lukács, R., Harangi, S., Guillong, M., Bachmann, O., Fodor, L., Buret, Y., Dunkl, I., Sliwinski, J., von Quadt, A., Peytcheva, I., Zimmerer, M., 2018. Early to Mid-Miocene syn-extensional massive silicic volcanism in the Pannonian Basin (East-Central Europe): eruption chronology, correlation potential and geodynamic implications. Earth-Science Reviews, 179, 1-19. https://doi.org/10.1016/j.earscirev.2018.02.005

Menzl, F., 1988. Genese und Alter der Kaolinlagerstätte Krumnußbaum an der Donau (Niederösterreich). Archiv für Lagerstättenforschung der Geologischen Bundesanstalt, 9, 67-72.

Meszar, M., 2018. Clay mineralogy of Miocene mudstones of the Lower Austrian Molasse Basin. Unpublished Master's Thesis, University of Vienna, Vienna, Austria, 115pp.

Meunier, A., 2005. Clays. Springer-Verlag Berlin Heidelberg, XIV + 472. https://doi.org/10.1007/b138672
Migoñ, P., 2003. Paleoweathering record and paleosurfaces in the Bohemian Massif, Central Europe and Fennoscandian Shield, Northern Europe. A basis for East-West comparisons. Géologie de la France, 1, 53-56.

Moore, D.M., Reynolds, R.C., 1997. X-ray diffraction and the identification and analysis of clay minerals (2nd ed.). Oxford University Press, Oxford, 378 pp. https://doi.org/10. 1017/S0016756898501501

Nehyba, S., Roetzel, R., 1999. Lower Miocene Volcaniclastics in South Moravia and Lower Austria. Jahrbuch der Geologischen Bundesanstalt, 141/4, 473-490.

Palzer-Khomenko, M., Wagreich, M., Kallanxhi, M.-E., Soliman, A., Knierzinger, W., Meszar, M., Gier, S., 2018a. Facies, paleogeography and stratigraphy of the Lower Miocene Traisen Formation and Wildendürnbach Formation (former "Oncophora Beds) in the Molasse Zone Lower Austria. Austrian Journal of Earth Sciences, 111/1, 75-91. https:// doi.org/10.17738/ajes.2018.0006

Palzer-Khomenko, M., Wagreich, M., Knierzinger, W., Meszar, M., Gier, S., Kallanxhi, M.-E., Soliman, A., 2018b. A calcite crisis unravelling Early Miocene (Ottnangian) stratigraphy in the North Alpine-Carpathian Foreland Basin: A lithoand chemostratigraphic marker for the Rzehakia Lake System. Geologica Carpathica, 69/4, 315-334. https://doi. org/10.1515/GEOCA-2018-0019

Piller, W.E., Egger, H., Erhart, C.W., Gross, M., Harzhauser, M., Hubmann, B., van Husen, D., Krenmayr, H.-G., Krystyn, L., Lein, R., Lukeneder, A., Mandl, G.W., Roegl, F., Roetzel, R., Rupp, R., Schnabel, W., Schönlaub, H.P., Summersberger, H., Wagreich, M., Wessely, G., 2004. Die stratigrafische Tabelle von Österreich 2004 (sedimentäre Schichtfolgen). Kommission für die paläontologische und stratigrafische Erforschung der Österreichischen Akademien der Wissenschaften und Österreichische Stratigraphische Kommission, Vienna.

Piller, W.E., Harzhauser, M., Mandic, O., 2007. Miocene Central Paratethys stratigraphy - Current status and future directions. Stratigraphy, 4/2-3, 151-168.

Pippèrr, M., Reichenbacher, B., 2017. Late Early Miocene palaeoenvironmental changes in the North Alpine Foreland Basin. Palaeogeography, Palaeoclimatology, Palaeoecology, 468, 485-502. https://doi.org/10.1016/j.palaeo.2017.01.002

Pippérr, M., Reichenbacher, B., Kirscher, U., Sant, K. and Hanebeck, H., 2018. The middle Burdigalian in the North Alpine Foreland Basin (Bavaria, SE Germany) - a lithostratigraphic, biostratigraphic and magnetostratigraphic re-evaluation. Newsletters on Stratigraphy, 51/3, 285-309. Roegl, F., Steininger, F.F., 1983. Vom Zerfall der Tethys zu Mediterran und Paratethys: Die neogene Paläogeographie und Palinspastik des zirkum-mediterranen Raumes. Annalen des Naturhistorischen Museums in Wien: Serie A, 85, 135-163.

Roetzel, R., 2010. Geologie und Geomorphologie im Nationalpark Thayatal-Podyjí. Wissenschaftliche Mitteilungen Niederösterreichisches Landesmuseum, 21, 35-66.

Roetzel, R., Reháková, Z., 1991. Haltepunkt 20 Weitersfeld - Lagerhaus. In: Arbeitstagung der Geologischen 
Bundesanstalt 1991 Geologie am Ostrand der Böhmischen Masse von Niederösterreich Schwerpunkt Blatt 21 Horn, Geologische Bundesanstalt, Wien, pp. 204-206.

Roetzel, R., Coric, S., Galovic, I., Rögl, F., 2006. Early Miocene (Ottnangian) coastal upwelling conditions along the southeastern scarp of the Bohemian Massif (Parisdorf, Lower Austria, Central Paratethys). Beiträge zur Paläontologie, 30, 387-413.

Roetzel, R., Krenmayr, H. G., Ćorić, S., Rögl, F., 2013. Exkursion E2 - Fazies und Stratigrafie der oligozänen und miozänen Sedimente in der alpinen Vortiefe auf den Blättern 55 Ober-Grafendorf und 56 St. Pölten: Haltepunkt E2/6: Untermamau - Sandgrube Spring. In: Gebhardt, H. (ed.), Arbeitstagung 2013 der Geologischen Bundesanstalt Geologie der Kartenblätter 55 Ober-Grafendorf und 56 St. Pölten, Melk 23.-27. September 2013, Geologische Bundesanstalt, Wien, pp. 236-269.

Roetzel, R., Wimmer-Frey, I., de Leeuw, A., Mandic, O., Márton, E., Nehyba, S., Kuiper, K., Scholger, R., 2015. Lower Miocene (upper Burdigalian, Karpatian) volcanic ash-fall at the south- eastern margin of the Bohemian Massif in Austria - new evidence from 40Ar/39Ar- dating, palaeomagnetic, geochemical and mineralogical investigations. Austrian Journal of Earth Sciences, 107/2, 2-22.

Sant, K., V. Palcu, D., Mandic, O., Krijgsman, W., 2017. Changing seas in the Early-Middle Miocene of Central Europe: a Mediterranean approach to Paratethyan stratigraphy. Terra Nova, 29/5, 273-281. https://doi.org/10.1111/ter.12273

Saussure, H.B. de, 1779. Voyages dans les Alpes. Neuchatel (Fauche-Borel), 540 pp.

Schultz, L., 1964. Quantitative Interpretation of Mineralogical Composition from X-ray and Chemical Data for the Pierre Shale. United States Geological Survey, Professional Paper, 0391-C.

Sinclair, H.D., 1997. Tectonostratigraphic model for underfilled peripheral foreland basins: An Alpine perspective. Geological Society of America Bulletin, 109, 324-346.

Steininger, F.F., Roetzel, R., 1999. Älteres Tertiär. Schriftenreihe des Waldviertler Heimatbundes, 38, 75-76.
Steininger, F.F., Wessely, G., Rögl, F., Wagner, L., 1986. Tertiary sedimentary history and tectonic evolution of the Eastern Alpine Foredeep. Giornale di Geologica, 48, 285-297.

Steininger, F., Wessely, G., 2000. From the Tethyan Ocean to the Paratethys Sea: Oligocene to Neogene Stratigraphy, Paleogeography and Paleobiogeography of the circum-Mediterranean region and the Oligocene to Neogene Basin evolution in Austria. Mitteilungen der Österreichischen Geologischen Gesellschaft, 92, 95-116.

Wagner, L.R., 1998. Tectono-stratigraphy and Hydrocarbons in the Molasse Foredeep of Salzburg, Upper and Lower Austria. Geological Society London Special Publications 134/1, 339-369

Weber, L., 1997. Kaolinbezirk Mühl- und Waldviertel. In: Weber, L. (ed.), Archiv für Lagerstättenforschung der Geologischen Bundesanstalt, 19, 235.

Werneck, W.L., 1980. Oberösterreichs Rohstoffvorkommen in Raum und Zeit. Jahrbuch des oberösterreichischen Musealvereines Gesellschaft für Landeskunde, 125/1.

Wessely, G., 2006. Niederösterreich. Geologische Bundesanstalt, Vienna, 416 pp.

Wimmer-Frey, I., Ćorić, S., Peresson, M., Rabeder, J., 2013. Mineralogische und korngrößenmäßige Untersuchungen an quartären und miozänen Sedimenten auf den Kartenblättern 55 Ober-Grafendorf und 56 St. Pölten. In: In: Gebhardt, H. (ed.), Arbeitstagung 2013 der Geologischen Bundesanstalt Geologie der Kartenblätter 55 Ober-Grafendorf und 56 St. Pölten, Melk 23.-27. September 2013, Geologische Bundesanstalt, Wien, pp. 138-140.

Received: 07.10.2019

Accepted: 30.07 .2020

Editorial handling: Gabor Tari 